\title{
The Adaptation of Antisocial Beliefs and Attitudes Scales: Case from Turkish Perspective
}

\author{
Lili Hurioğlu*, Songül Tümkaya \\ Department of Primary School Teaching, Faculty of Education, Cukurova University, Turkey
}

Copyright $(2016$ by authors, all rights reserved. Authors agree that this article remains permanently open access under the terms of the Creative Commons Attribution License 4.0 International License

\begin{abstract}
This study is focused on adapting the scales known as Antisocial Beliefs and Attitudes Scales (ABAS) into Turkish version. The general aim of the study is to propound the Turkish version of the ABAS and to see if the scale functions in a similar fashion in Turkey in terms of its psychometric properties. The scales were applied to 1938 individuals between the ages of 9 and 16. Exploratory factor analysis (EFA) and confirmatory factor analysis (CFA) were performed, and the correlations of all relevant points were calculated. On the strength of the outcomes obtained from the EFA, a three-factor structure emerged. Confirmatory factor analysis verified the three-factor structure. Criterion-related and discriminant validity of the scales, as well as gender and age-related validity were examined. For reliability, test-retest correlations and the Cronbach's alpha scores were calculated. Our findings show that the ABAS were able to provide both sub-scale measurement points, and general antisocial attitudes and beliefs points.
\end{abstract}

Keywords Antisocial Beliefs and Attitudes, Validity, Reliability, Child, Adolescence

\section{Background of Research Problem}

Youths who show antisocial behaviors can create great risk for themselves, their families, and for society in general. Such behaviors, including violence, aggressiveness, and criminal acts such as stealing and vandalism, occur in the early years of childhood and increase rapidly in the following years $[1,2]$.

According to the statistics of the Ministry of Justice in Turkey, the number of children between the ages of 12 and 18 , who were sentenced to prison by criminal courts in 2005 , was 4290; this number has increased year by year, reaching 8333 in the year 2008 and 44352 in year 2013 (Republic of Turkey, Ministry of Justice). From these rates, it can be indicated that juvenile delinquency greatly increased in recent years in Turkey. When the crime types are examined, the following can be observed: First, there are crimes that are committed against assets, and second, there are crimes committing bodily harm [3]. Furthermore, these results not only illustrate the dramatic rise in the number of juvenile criminals over the years but may also foreshadow the future teenage and adult criminals. Therefore, it is important from the perspectives of the individual, the family, and the society to identify and prevent antisocial beliefs in childhood, as these may serve as strong predictors for future criminal involvement in later years $[4,56,7,8,9,10]$.

The term antisocial behavior suggests a wide array of behaviors; hence it is hard to define for many scientists [11]. However, there is a consensus that antisocial behaviors are serious acts that include deliberate theft, vandalism, physical violence and criminal behavior which are a subset of antisocial behaviors that violate criminal law $[1,2,5,12]$. On the other hand, Clarke [13, p. 7] states that antisocial behaviors are acts that eliminate the feeling of anxiety and lack of emotions towards the affluence and general ease of others. According to Kaner [14, p.187], behaviors included here are determined by the society and social norms, and acts that harm the rights of others. From the above views, the term antisocial behavior can be defined as acts that include deliberate disobeying of the rules of the society and that have criminal attributes in general.

On the other hand, antisocial attitude is defined by Simourd [15] as the individual's positive/negative evaluation of whether to commit a criminal act, and the individual's perception of the social pressure surrounding the act that he/she wants to do. However, antisocial beliefs are explained as a distrust of individuals who represent authority (police, judges, lawyers, etc.), as a perception of the world as an unsafe place, as an approval of solutions that include aggression, and as an identification of the self with outlaw peers [16].

When the relevant literature is reviewed, it can be observed that antisocial behavior is commonly examined in relation to a wide array of variables such as age, gender, and socio-economic level. Longitudinal studies such as the "Dunedin Study" have shown that antisocial behavior follows developmental routes that start in pre-school stage and continue into early adulthood. Interestingly, these behaviors reveal themselves with consistent structures or 
characteristics that continue until at least early adulthood. The consistent externalization of these antisocial behaviors occurs as early as primary school years for many children $[8$, $17,18,19,20,21]$.

Although most children behave in difficult and uneasy ways, literature suggests that boys engage in antisocial and impulsive acts more frequently than girls [9, 22, 23, 24, 25]. In a study carried out by Tuvblad, Eley and Lichtenstein [25], it was observed that while inheritance plays a role in girls' antisocial and aggressive behaviors, environmental factors are more influential in boys. The presence of these antisocial behaviors also increases the possibility of engaging in unlawful acts in later years $[4,5,9]$. However, it is crucial to state that this situation does not mean that all children who behave problematically will turn out to be chronic criminals [26].

Many studies claim that there is a meaningful correlation between antisocial beliefs/attitudes and juvenile delinquency $[7,27,28]$. The large-scale cross-sectional study conducted by Mak [28] in Australia posited the idea that antisocial beliefs and values are among the variables that are most strongly related to juvenile delinquency. Thus, it is thought that measuring antisocial attitudes can provide information about antisocial behaviors, and also the detection of negative attitudes in early years can be important to treating problems before they occur. Therefore, it is essential to highlight the relationship between antisocial attitudes and behaviors to perform prevention studies that involve parents, teachers, and administrators.

The evaluation of relevant studies reveals that the beliefs and attitudes of children usually reflect behavior at later ages and also their antisocial behavioral problems are strong predictors for criminal involvement later in life [7, 29, 30, 31, 32, 33]. Moreover, studies concerned with the costs of antisocial behavior for families and society illustrate the seriousness of the problem from a different perspective. Families that are affected by delinquent behaviors are the families that can be considered at risk. In other words, antisocial behavior is more frequently observed in children who experience domestic violence [34, 35]. For this reason, it is clear that antisocial attitudes, families, and the environment play important roles in the emergence and persistence of criminal acts in individuals' lives.

The Turkey Statistical Institute (TSI) and the General Directorate of Criminal-Records and Statistics have published data that help to describe juvenile delinquency in Turkey. It details the numbers of children who ended up in security departments in 27 cities in relation to year and gender (these statistics are updated once every five years). According to the TSI records, the number of children who were brought to a security department in 2002 was 52064; in 2006 , this number was 81110 . These numbers have risen annually. Furthermore, the most frequently committed juvenile crimes are theft, extortion, assault and battery, murder, fraud, arson, and larceny [36]. According to records of the General Directorate of Criminal-Records and Statistics for the year 2008, among the cases brought to juvenile and juvenile high crimes courts (which are arranged according to crime type, gender, and age), the most frequent crimes were theft, fraud, looting, and extortion; and the second most frequent types of crimes were ones related to bodily harm such as mutilation, murder, torture, persecution, and organ trafficking.

Köknel [37, p.356] states that, in Turkey, nearly half of the criminal acts are committed by children and teenagers younger than 25 ; additionally, $90 \%$ of the adult crimes are committed by people who also committed crimes in their childhood and teenage years. Avc1's [38] study of the underlying social reasons for children's tendencies towards crime that was performed with children who had been arrested and were under the age of 18 found that immigration of the family (children whose families migrated from rural areas to urban), housing and demographic characteristics, school, friends, and how the children spent their spare time affected criminal tendencies in the children. Furthermore, Kocadaş's [39] study, which examined the relationship between low socio-economic structure and crime, claimed that, compared to children under the age of 11, children between 11 and 18 commit more crimes, and children who come from families with low education levels commit more crime than other children. Finally, Akduman, Akduman, and Cantürk [40] examined the individual and family characteristics related to adolescent delinquency and found that boys are more frequently involved in criminal acts than girls, that crime rates increase with age that the majority of the children who commit crimes do not attend school, and that children usually commit crimes with their friends.

In summary, it can be stated that, as in other studies, family, environment, peer influence, age, gender, family education level, and family relations are risk factors for antisocial behavior and tendencies toward criminal acts. Despite all these findings, no studies that define children's antisocial attitudes in early years were observed. Because studies related to preventive services have gained importance all around the world, studies that measure children's antisocial beliefs and attitudes are needed and will contribute to necessary precautions being taken. In Turkey, there is no scale, either developed or adapted, that measures antisocial beliefs and attitudes in the early years of life. Thus, a scale that measures antisocial beliefs and attitudes in young children is needed. First, the following advantages of adapting a scale rather than developing a new scale should be considered; scale adaptation allows for ease in communicating and comparing national, ethnic, and cultural groups at the national and international levels [41, 42, 43, 44]. Adaptation costs less - and adaptation can be created in a shorter time than a new scale can be developed [41, 42, 43, 45] - and the researcher does not need to have a great deal of theoretical background in the related area $[42,43]$. Based on the above assumptions, the research aims to adapt the Antisocial Beliefs and Attitudes Scales (ABAS) developed by Butler, Leschied, and Fearon [46] into the Turkish version and test the validity and reliability studies of the adapted scale. 


\section{Characteristics of Original ABAS}

The Antisocial Beliefs and Attitudes Scale, developed by Butler, Leschied, and Fearon [46] was designed to measure the antisocial beliefs and attitudes of children aged between 9 and 16 , and is based on experimental literature related to childhood behavioral problems and juvenile crime, accordingly.

The ABAS was developed based on Andrews and Bontas' [47] The Psychology of Criminal Conduct Theory. This theory shows that antisocial thoughts are risk factors for youth crime; moreover, such thoughts can be accepted as a foundation for understanding the social psychology of criminal conduct. Andrews and Bonta [47] claimed that the main risk factors for childhood and youth criminal conduct were antisocial attitudes, antisocial friends, antisocial behavior history, antisocial personalities, home, school, work, and problematic circumstances experienced during spare time.

The validity and reliability studies of the scale were carried out with 181 male and 233 female students $(\bar{X}=14.18$, $\mathrm{df}=231$ ) aged between 9 and 16 years from primary and high schools from Toronto, which is in the state of Ontario in Canada. This age group was chosen to study antisocial beliefs in late childhood and puberty. Sixty-one percent of this sample was from low socio-economic background schools, and the remaining sample was from high socio-economic schools. The KMO value, which measures the suitability of the sample for analysis, was .87 , and the outcome of the Barlett's Test was meaningful $\left(\chi^{2}\right.$ $(861)=4371.34, p<.001)$. The construct validity of the scale was measured with principal component analysis (PCA) varimax rotation. This analysis produced a three-factor structure with eigenvalues $8.24,2.65$, and 2.10. These factors were named "Rule Non-Compliance", "Self-Serving Justification", and "Peer Conflict". It was determined that there should be a structure composed of 34 items that fit the criterion defined by factor analyses (lowest factor loading is .40). The item factor loads varied between .40 and .66 . Cronbach's alpha coefficients for the sub-scales were .83 for the "Rule Non-Compliance" sub-scale, .76 for the "Self-Justification" sub-scale, and .78 for the "Peer Conflict" sub-scale. The scale composed of 34 items is designed in the form of 3-point likert scores in which Agree is 2 points, Not Sure is 1 point, and Disagree is 0 point. Moreover, items (2, $3,5,6,7,9,12,13,14,25,31$, and 33) in the ABAS are reverse scored. All in all, high scores on the scale indicate strong antisocial beliefs and attitudes.

\section{Method}

This research is a study of the Turkish adaptation of the ABAS, which aims to measure antisocial beliefs and attitudes in children between 9 and 16 years old. This study consisted of four parts including translation, a pilot study, a field study, and an investigation of psychometric properties as shown in Figure 1.

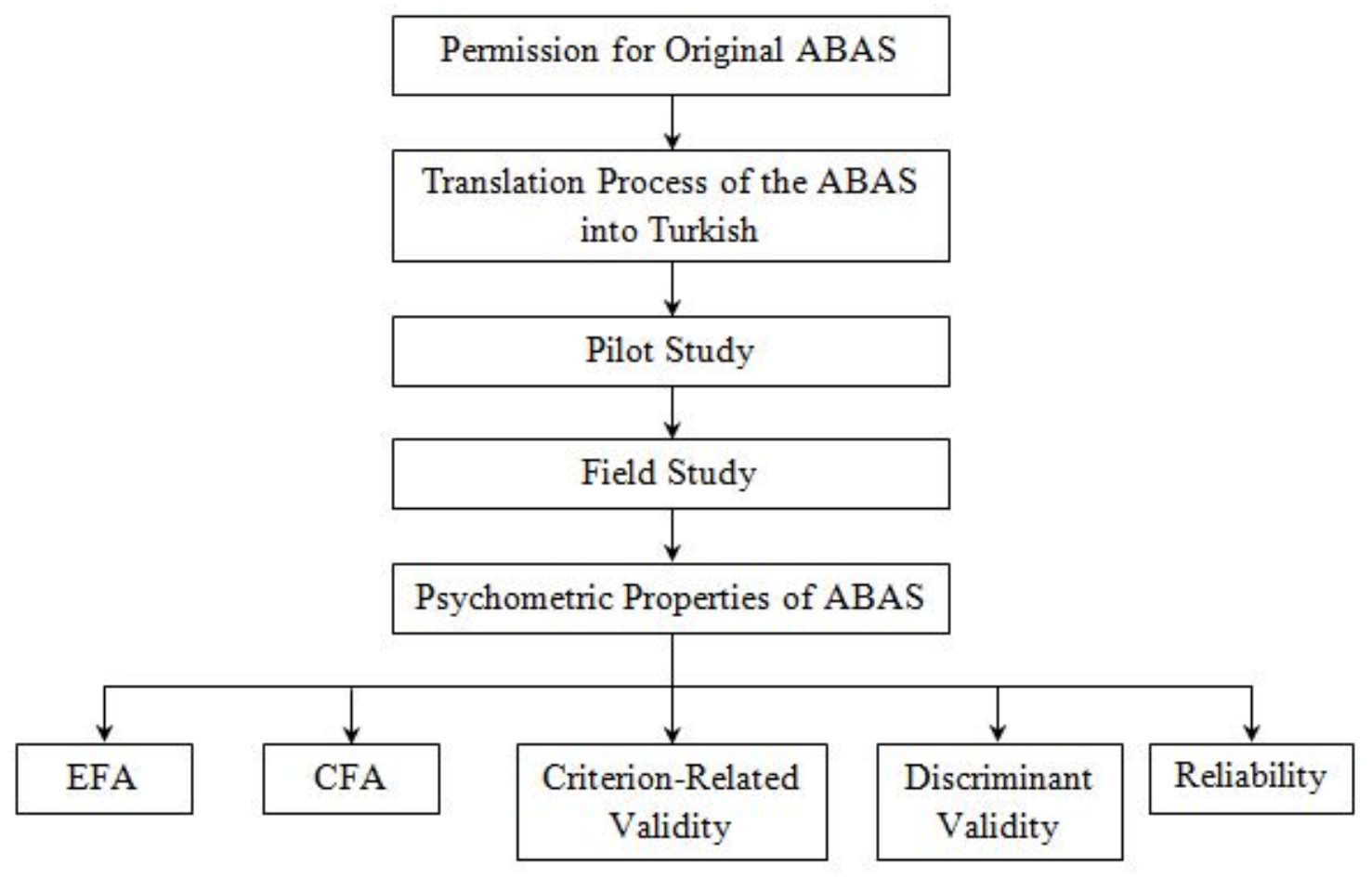

Figure 1. Analysis process chart of the research. 


\section{Permission for Use of ABAS}

Having decided to adapt the original ABAS to the Turkish version as well as investigating the adaptation of the ABAS, permission was obtained from Butler, Leschied, and Fearon [46] via e-mail.

\section{Translation Process of the ABAS into Turkish}

Translation is the first step in test adaptation; in order to test the grammatical validity of the ABAS that was translated from the source language (English) into the target language (Turkish). Hence, one-way translation techniques such as back-translation questioning, group translation, and re-translation were performed on the Turkish translation process of the items of the ABAS. During the translation process, the items of the ABAS were translated into Turkish independently by six PhD experts who studied in Britain and America, as they have brilliant knowledge about both languages (English and Turkish) and culture. Thereafter, the six experts worked on the items as a group, in which they discussed on the meaning, grammar and spelling structures of the items. To examine how the scale functioned in the designated population in terms of clarity of items, a preliminary study was conducted with 54 students. There were 31 female $(57.4 \%)$ and 23 male $(42.6 \%)$ students who were randomly selected from all grades (primary school $3^{\text {rd }}$, $4^{\text {th }}, 5^{\text {th }}$; middle school $6^{\text {th }}, 7$ th, $8^{\text {th }}$; high school $9^{\text {th }}$ ) and their ages were between 9 and 16. After the pilot study, the experts re-translated the items into the original language. These items were sent to the second author of the original ABAS, A. W. Leschied, for examination via e-mail. Based on the feedback given by Leschied, the items of the scale were revised and the ABAS were finalized.

\section{Field Study}

The field study comprised 1938 students between 9 and 16 years old receiving education in the $3^{\text {rd }}$ through the $10^{\text {th }}$ grade in the central regions (Seyhan, Çukurova, Yüreğir, Sarıçam) of Adana, Turkey where a written permission and official statistical reports which show the socio-economic status of the schools were obtained from the Provincial Directorate of Education in Adana. Based on the official statistical reports, study sample was created with a cluster random sampling through the selected grades from low, middle and upper socio-economic level. Sixty percent of the sample was from low, $20 \%$ from middle, and the remaining $20 \%$ were from upper socio-economic level schools. This part of the study was applied to 2000 students from 46 different schools. Unfortunately, 62 of the total number of students were omitted from the research as they had not answered the items of the scales correctly (missing values). In total, 1938 forms were found relevant to be included in the study. The sample consisted of 1003 female $(52 \%)$ and 935 male $(48 \%)$ students. School, gender, grade level, and age information related to the primary (first and secondary stage) and high school students that constituted the sample are presented in Table 1.

Table 1. Demographic Information of the Students in the Sample.

\begin{tabular}{|c|c|c|c|c|c|c|}
\hline \multirow{2}{*}{ Grade Level } & \multirow{2}{*}{ Age } & \multicolumn{3}{|c|}{ Gender } & \multicolumn{2}{|c|}{ Total } \\
\hline & & & $\mathrm{n}$ & $\%$ & $\mathrm{n}$ & $\%$ \\
\hline \multirow{2}{*}{$3^{\text {rd }}$ grade } & \multirow{2}{*}{$9-10$} & Girl & 116 & 51.8 & \multirow{2}{*}{224} & \multirow{2}{*}{100} \\
\hline & & Boy & 108 & 48.2 & & \\
\hline \multirow{2}{*}{$4^{\text {th }}$ grade } & \multirow{2}{*}{$10-11$} & Girl & 128 & 55.9 & \multirow{2}{*}{229} & \multirow{2}{*}{100} \\
\hline & & Boy & 101 & 44.1 & & \\
\hline \multirow{2}{*}{$5^{\text {th }}$ grade } & \multirow{2}{*}{$11-12$} & Girl & 130 & 51 & \multirow{2}{*}{255} & \multirow{2}{*}{100} \\
\hline & & Boy & 125 & 49 & & \\
\hline \multirow{2}{*}{\multicolumn{2}{|c|}{ First Level Total }} & Girl & 374 & 52.8 & \multirow{2}{*}{708} & \multirow{2}{*}{100} \\
\hline & & Boy & 344 & 47.2 & & \\
\hline \multirow{2}{*}{$6^{\text {th }}$ grade } & \multirow{2}{*}{$12-13$} & Girl & 129 & 51 & \multirow{2}{*}{253} & \multirow{2}{*}{100} \\
\hline & & Boy & 124 & 49 & & \\
\hline \multirow{2}{*}{$7^{\text {th }}$ grade } & \multirow{2}{*}{$13-14$} & Girl & 124 & 48.2 & \multirow{2}{*}{257} & \multirow{2}{*}{100} \\
\hline & & Boy & 133 & 51.8 & & \\
\hline \multirow{2}{*}{$8^{\text {th }}$ grade } & \multirow{2}{*}{$14-15$} & Girl & 128 & 49.6 & \multirow{2}{*}{258} & \multirow{2}{*}{100} \\
\hline & & Boy & 130 & 50.4 & & \\
\hline \multirow{2}{*}{\multicolumn{2}{|c|}{ Second Level Total }} & Girl & 374 & 52.8 & \multirow{2}{*}{708} & 100 \\
\hline & & Boy & 344 & 47.2 & & \\
\hline $\mathrm{Q}^{\text {th }}$ orade & 15 & Girl & 124 & 53.4 & 232 & 100 \\
\hline 5 grade & 10 & Boy & 108 & 46.6 & $2 J 2$ & 100 \\
\hline $10^{\text {th }}$ orade & 16 & Girl & 124 & 53.9 & 230 & 100 \\
\hline 10 graue & 10 & Boy & 106 & 46.1 & 250 & 100 \\
\hline His & & Girl & 248 & 53.7 & 67 & 100 \\
\hline Hig & & Boy & 214 & 46.3 & 402 & 100 \\
\hline Total & & Girl & 1003 & 52 & 1938 & 100 \\
\hline Total & & Boy & 935 & 48 & 1500 & 100 \\
\hline
\end{tabular}


The number of students who completed the scale in the first stage of primary school was 708; out of which 374 $(52.8 \%)$ were female and $344(47.2 \%)$ were male. In the secondary stage of primary schools, 768 students were administered the scale, and $381(49.6 \%)$ of these were females and 387 (50\%) were males. Finally, a total of 462 high school students were administered the scale; 248 $(53.7 \%)$ were females and the remaining 214 (46.3\%) were males.

\section{Psychometric Properties of ABAS}

In this stage, firstly, dataset obtained from field study ( $\mathrm{n}=1938$ students) was organized in terms of the reverse scored items $(2,3,5,6,7,9,12,13,14,25,31$, and 33). Next, outlier analysis, missing value analysis as well as the normality (One-sample Kolmogorov-Smirnov Test) of the data were tested. Finally, to determine the psychometric properties of ABAS, explanatory factor analysis (EFA), confirmatory factor analysis (CFA), criterion-related validity, discriminant validity and the reliability analysis were tested respectively. Moreover, detailed information about each psychometric property of ABAS was given in the following sections.

EFA of the ABAS. Determining the organized data (see previous section); to ascertain whether similar latent constructs with original latent constructs of ABAS or not, EFA analysis was carried out.

CFA of the ABAS. According to the results of the EFA which shows the latent constructs (factors) or observed variables of the data set, CFA was implemented to ascertain whether they are related to the specified constructs/latent factors or not.

Criterion-related validity. To determine the criterion-related validity of the adapted ABAS, age, gender as well as similar scales as Violence scale (VS), Behavior rating scale (BRS), Aggression scale (AS) and Youth self report (YSR/11-18) were applied to a total of $8163^{\text {rd }}$ through $8^{\text {th }}$ grade students and $9^{\text {th }}$ through $10^{\text {th }}$ grade (primary-middle and high schools) students from 34 different schools. Table 2 illustrates the related number of students, grades, and the similar scales used.

Table 2. Number of Students, Grades, and Scales Used for the Similar Scale Validity.

\begin{tabular}{|c|c|c|}
\hline Similar Scales & Grade Level & $\mathrm{n}$ \\
\hline $\begin{array}{c}\text { Behavior Rating Scale } \\
(\text { BRS) }\end{array}$ & $3^{\text {rd }}$ and $4^{\text {th }}$ grade & 98 \\
\hline $\begin{array}{c}\text { Youth Self-Report } \\
\text { (YSR/11-18) }\end{array}$ & $3^{\text {rd }}, 4^{\text {th }}$ and $5^{\text {th }}$ grade & 150 \\
\hline Violence Scale (VS) & $7^{\text {th }}$ and $8^{\text {th }}$ grade & 124 \\
\hline Aggression Scale (AS) & $3^{\text {rd }}, 4^{\text {th }}, 5^{\text {th }}, 6^{\text {th }}, 7^{\text {th }}, 8^{\text {th }}, 9^{\text {th }}$ and & 444 \\
\hline Total & $10^{\text {th }}$ grade & 816 \\
\hline
\end{tabular}

Moreover, detailed information about the similar scales used as criterion is given below:

Violence scale (VS). This scale was developed by Yavuz
[48] and is based on the violence scale proposed by Karakaya [49]. The violence scale is a 19-item 3-point Likert scale (disagree, partially agree, agree) that aims to measure $7^{\text {th }}$ and $8^{\text {th }}$ grade students' attitudes toward violence in schools. The sub-scales are "Trusting" (8 items), "Explicit Violence" (6 items), and "Implicit Violence" (5 items). Their alpha values are $.88, .91, .90$, respectively.

Behavior rating scale (BRS). This scale was developed by Şahin [50] and aims to measure the aggression levels of students at primary school first section, whose ages varied between 10 and 11 years; it is an 18-item scale with three possible answers for each item: "I always do", "I sometimes do", and "I never do". The Cronbach's alpha coefficient of the aggression scale was calculated as .77; the stability level of the scale was .71 $(\mathrm{p}<.01)$.

Aggression scale (AS). This scale was developed by Buss and Warren [51] to evaluate anger and aggression. It is a 34-item 3-point Likert scale with five sub-scales. The sub-scales evaluate physical aggression, verbal aggression, anger, hostility, and indirect aggression. Turkish validity and reliability tests of the scale were carried out by Can [52]. The Cronbach's alpha coefficient is .95 , and the test-retest correlation is $r=.760$; Cronbach's alpha coefficients for the sub-scales are as follows: physical aggression was $\mathrm{r}=.847$; verbal aggression was $\mathrm{r}=.696$; anger was $\mathrm{r}=.746$; hostility was $\mathrm{r}=.810$; indirect aggression was $\mathrm{r}=.857$; and total aggression was $r=.857$.

Youth self report (YSR/11-18). This test was developed by Achenbach and Edelbrock [53] to systematically evaluate self-stated talents and problematic behaviors of youths aged between 11 and 18 years. The test was adapted to Turkish by Erol [54] and it is comprised of 17 talent and 112 problematic behavior items. Problematic behaviors are rated according to the frequency of their appearance over the last 6 months: 0 (Not True), 1 (Sometimes or A Little True), 2 (Very or Frequently True). Scores from the scales of "Internalization", "Externalization", and "Total Problem" are recorded. The Cronbach's alpha values for "Internalization Problems", "Externalization Problems", and "Total Problems" are .80, .81, and .89, respectively.

Discriminant validity. Totally eighty-five $(n=85)$ children participated in the process of determining discriminant validity of the adapted ABAS. Twenty-seven of them comprised of children aged between 13 and 16 years who had been brought to the Children's Branch of the Adana Security Directorate with a commitment of a crime claim. The mean age of this group was 15.37, and the standard deviation was 1.04. In the other part of the sample, there were fifty eight $(\mathrm{n}=58)$ children whose ages ranged from 12 to 16 and the mean age for this group was 15.20 with a standard deviation of .97 in the M-type juvenile prison in Pozant1, Adana. The adapted ABAS was applied on 85 children from the Children's Branch of the Adana Security Directorate and M-type juvenile prison in Pozant, Adana. Since no girls were taken into custody within the duration of the study, all data were obtained from boys.

Reliability. To test the reliability of adapted ABAS, 
test-retest reliability analysis was applied on 195 students, of which $53.3 \%$ of them were female $(n=104)$ and the other students $46.7 \%$ were male $(n=91)$. The test retested students were from eight different schools and tested over four-week intervals. Finally, test-retest correlation for the sub-scales and total score measurements were determined. Furthermore, testing of the internal consistency of the adapted ABAS for each sub-scale score was calculated by means of Cronbach's alpha reliability coefficient.

\section{Findings}

\section{EFA of the ABAS}

The KMO value of the 34 item ABAS was .94, and the chi-square value obtained from a Barlett's test was found to be meaningful $\left(\chi^{2}=15270.546, \mathrm{sd}=561, \mathrm{p}<.001\right)$. The items co-variance values ranged from .11 to .58 . An explanatory factor analysis reached a five-factor solution for which the eigenvalue was over 1.00; this analysis described over $31 \%$ of the variance. The eigenvalues of the factors were 8.04 , $1.92,1.67,1.18$, and 1.10; a line graph of the factors with these eigenvalues is presented below in Figure 2.

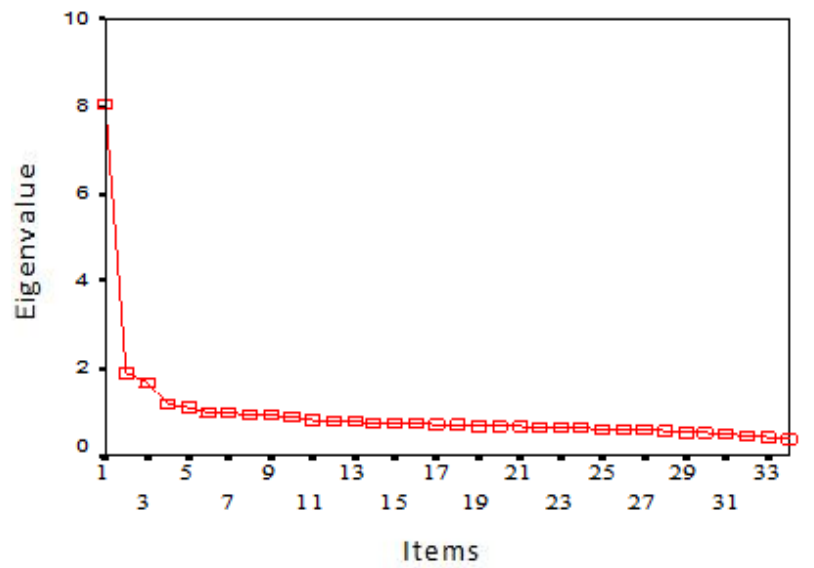

Figure 2. Unweighted least squares factor analysis scree plot of eigenvalues.

When the graph of the factors, according to their eigenvalues in Figure 2 was examined, it was determined that examining the structure in terms of 3 factors would be convenient. This decision was made as the breaks considered important occurred after the $3^{\text {rd }}$ factor, and the difference between the eigenvalues of the 4 th $(1.18)$ and $5^{\text {th }}$ factors (1.10) was small (.08). Thus, the unweighted least squares method with the promax rotation technique was used to try to reach a three-factor solution. Analysis of the factor loads for the items revealed that 30 of the 34 items met the criterion defined for the three factors (factor loads were required to exceed .30 , and the difference between the two factor loads were to be at least (.10). Factors and factor loadings of the 3 -factor structure, which reached a solution, are presented in Table 3.

From Table 3, it is apparent that 15 items (please refer to appendix for full item statements in the final version of the adapted scale) with factor loads ranging from .37 to .73 were loaded into the first factor and that the eigenvalue for this factor was 8.04 , which accounted for $21.66 \%$ of the variance. Only five items (numbers 1, 2, 4, 11 and 15) were loaded into the first factor and then settled into their own factor in the original form. The remaining items were placed in the $2^{\text {nd }}$ and $3^{\text {rd }}$ factors. The 10 items of the $2^{\text {nd }}$ factor had factor loadings between .32 and .54 . The eigenvalue for this factor was 1.92 , which accounted for $3.52 \%$ of the variance. Except for number 25, all items belonged to the $1^{\text {st }}$ factor in the original scale. In this sampling, these items are in the $2^{\text {nd }}$ rather than the $1^{\text {st }}$ factor. Five items were found in the $3^{\text {rd }}$ factor, which had factor loadings between .31 and .71 . The eigenvalue of the $3^{\text {rd }}$ factor was 1.47 , which accounted for $2.87 \%$ of the variance. All items in this factor are items that belong to the $2^{\text {nd }}$ factor in the original scale. Items $10,20,24$, and 34 were taken out of the scale since they did not meet the required loading criterion. The eigenvalue for the 3 -factor structure was 11.43 , and the total variance accounted for was $28.06 \%$.

At the end of the factor analysis, it was found that the ABAS had a 3-factored structure, as it did in the original form. The $1^{\text {st }}$ factor was named the "Aggression-Rule Non Compliance (ARNC)" sub-scale, the $2^{\text {nd }}$ factor was named the "Rule Compliance (RC)" sub-scale, and the $3^{\text {rd }}$ factor was named the "Self-Justification (SJ)" sub-scale. Since the dataset was not normally distributed, confirmatory factor analyses were performed with asymptotic covariance matrices and the unweighted least-squares method.

\section{CFA of the ABAS}

When the factor loadings obtained from the confirmatory factor analyses were examined, the items of the scale were observed, which were parallel with the three-factor implicit structure predicted by the factor analysis. The model given in Figure 3, and the standardized factor loads of the items in Figure 3 are given in Table 3 with $t$ and $R^{2}$ values. 
Table 3. The Reliability Coefficients of the ABAS obtained from Explanatory and Confirmatory Factor Analyses.

\begin{tabular}{|c|c|c|c|c|c|c|c|c|}
\hline \multirow[b]{3}{*}{ Subscales/Items } & \multicolumn{3}{|c|}{ EFA } & \multicolumn{4}{|c|}{ CFA } & \multirow[b]{3}{*}{$\mathrm{R}^{2}$} \\
\hline & \multicolumn{3}{|c|}{ (ULS-Promax Rotation) } & \multicolumn{4}{|c|}{ (ULS-Standardized Loads) } & \\
\hline & 1 & 2 & 3 & 1 & 2 & 3 & $\mathrm{t}$ & \\
\hline \multicolumn{9}{|c|}{ Aggression-Non-Compliance Rule } \\
\hline 29 & .74 & -.11 & .11 & .84 & & & 58.71 & .71 \\
\hline 17 & .72 & -.12 & & .64 & & & 32.07 & .41 \\
\hline 26 & .68 & -.17 & & .57 & & & 25.69 & .33 \\
\hline 11 & .61 & & -.11 & .59 & & & 27.09 & .35 \\
\hline 4 & .57 & & -.18 & .55 & & & 23.33 & .38 \\
\hline 27 & .54 & & .17 & .75 & & & 41.04 & .57 \\
\hline 23 & .53 & & .12 & .77 & & & 42.92 & .59 \\
\hline 31 & .50 & .16 & & .66 & & & 32.45 & .44 \\
\hline 28 & .49 & & .18 & .70 & & & 34.39 & .49 \\
\hline 1 & .48 & .12 & & .65 & & & 29.38 & .42 \\
\hline 30 & .47 & & .11 & .65 & & & 31.13 & .43 \\
\hline 2 & .43 & .29 & -.15 & .63 & & & 28.47 & .39 \\
\hline 15 & .42 & .1 & & .77 & & & 41.58 & .59 \\
\hline 32 & .40 & & & .48 & & & 19.21 & .23 \\
\hline 33 & .38 & .11 & -.12 & .47 & & & 18.34 & .22 \\
\hline \multicolumn{9}{|c|}{ Rule Compliance } \\
\hline 5 & & .55 & & & .62 & & 22.76 & .38 \\
\hline 9 & -.14 & .53 & & & .61 & & 18.03 & .37 \\
\hline 6 & -.18 & .52 & .10 & & .52 & & 15.66 & .27 \\
\hline 3 & & .44 & & & .53 & & 17.05 & .28 \\
\hline 14 & & .43 & & & .62 & & 22.28 & .38 \\
\hline 7 & .11 & .43 & & & .59 & & 22.17 & .34 \\
\hline 13 & .17 & .40 & & & .58 & & 20.73 & .34 \\
\hline 12 & & .39 & & & .58 & & 17.74 & .34 \\
\hline 8 & .12 & .38 & & & .75 & & 29.25 & .56 \\
\hline 25 & & .33 & & & .37 & & 12.12 & .14 \\
\hline \multicolumn{9}{|c|}{ Self-Justification } \\
\hline 19 & -.19 & & .72 & & & .73 & 21.73 & .53 \\
\hline 22 & & & .63 & & & .80 & 27.44 & .65 \\
\hline 16 & & & .51 & & & .62 & 18.96 & .39 \\
\hline 21 & .23 & & .42 & & & .79 & 31.00 & .62 \\
\hline 18 & & & .32 & & & .45 & 12.91 & .20 \\
\hline
\end{tabular}

The model related to the implicit structure composed of three sub-dimensions is presented in Figure 3 and Table 3. The chi-square statistic edited for the non-normal distribution of the model was found to be meaningful $\left(\chi^{2}=1358.70, \mathrm{sd}=402, \mathrm{p}<.001\right)$. Dividing the chi-square value by the degrees of freedom yielded 3.37. Examination of the fit indexes of the confirmatory factor analyses of the model in Table 3 revealed that the chi-square value was meaningful $\left(\chi^{2}=1358.70, \mathrm{~N}=1938, \mathrm{df}=402, \mathrm{p}=.000\right)$. However, chi-square analyses are affected by the sample size; specifically, as the sample gets larger, the meaningfulness of the chi-square value with regard to chance factors alone increases. Hence, it is necessary to look at $\chi^{2} / \mathrm{df}$ in large sample sizes $[55,56]$. In this context, $\chi^{2} / \mathrm{df}$ was calculated as 3.37. Other fit index values were as follows: $\mathrm{RMSEA}=.035$; $\mathrm{RMR}=.053 ; \quad \mathrm{SRMR}=.053 ; \quad \mathrm{GFI}=.053 ; \quad \mathrm{AGFI}=.053$; $\mathrm{NNFI}=.99 ; \mathrm{NFI}=.99$ and, $\mathrm{CFI}=.99$.

To examine the internal consistency of the Turkish version of the ABAS and examine the relationship between the total item and sub-scale scores, an analysis in which the score of each item was subtracted from the related sub-scale score was carried out. The results are presented in Table 4.

On the other hand, the correlation coefficients among the sub-scales of the Turkish form of the ABAS were calculated.
Furthermore, there were moderate correlations among the sub-scales as ARNC-RC $\left(\mathrm{r}_{\mathrm{x}}=.52 ; \mathrm{p}<.001\right)$, ARNC-SJ $\left(\mathrm{r}_{\mathrm{x}}=.47\right.$; $\mathrm{p}<.001)$, and $\mathrm{RC}-\mathrm{SJ}\left(\mathrm{r}_{\mathrm{x}}=.38 ; \mathrm{p}<.001\right)$ respectively.

Table 4. Means, Standard Deviations, and Item/Sub-scale Total Score Correlations of Items.

\begin{tabular}{|c|c|c|c|c|c|c|c|}
\hline Items & $\bar{X}$ & $\mathbf{s d}$ & $\mathbf{r}^{\mathbf{2}(\mathbf{a})}$ & $\mathbf{I t e m s}$ & $\bar{X}$ & $\mathbf{s d}$ & $\mathbf{r}^{\mathbf{2}(\mathbf{a})}$ \\
\hline $\mathbf{1}$ & .54 & .81 & .49 & $\mathbf{1 7}$ & .86 & .82 & .57 \\
\hline $\mathbf{2}$ & .52 & .74 & .48 & $\mathbf{1 8}$ & .31 & .59 & .29 \\
\hline $\mathbf{3}$ & .37 & .68 & .36 & $\mathbf{1 9}$ & .11 & .40 & .45 \\
\hline $\mathbf{4}$ & .92 & .88 & .46 & $\mathbf{2 1}$ & .34 & .59 & .39 \\
\hline $\mathbf{5}$ & .42 & .72 & .44 & $\mathbf{2 2}$ & .17 & .50 & .48 \\
\hline $\mathbf{6}$ & .30 & .64 & .38 & $\mathbf{2 3}$ & .44 & .71 & .58 \\
\hline $\mathbf{7}$ & .53 & .77 & .40 & $\mathbf{2 5}$ & .62 & .85 & .26 \\
\hline $\mathbf{8}$ & .32 & .66 & .42 & $\mathbf{2 6}$ & .96 & .87 & .57 \\
\hline $\mathbf{9}$ & .19 & .54 & .39 & $\mathbf{2 7}$ & .45 & .75 & .57 \\
\hline $\mathbf{1 1}$ & 1.04 & .83 & .50 & $\mathbf{2 8}$ & .51 & .77 & .53 \\
\hline $\mathbf{1 2}$ & .27 & .61 & .36 & $\mathbf{2 9}$ & .50 & .78 & .68 \\
\hline $\mathbf{1 3}$ & .43 & .70 & .38 & $\mathbf{3 0}$ & .49 & .76 & .50 \\
\hline $\mathbf{1 4}$ & .43 & .74 & .40 & $\mathbf{3 1}$ & .69 & .84 & .52 \\
\hline $\mathbf{1 5}$ & .40 & .73 & .53 & $\mathbf{3 2}$ & .71 & .82 & .38 \\
\hline $\mathbf{1 6}$ & .25 & .57 & .41 & $\mathbf{3 3}$ & .58 & .82 & .36 \\
\hline
\end{tabular}




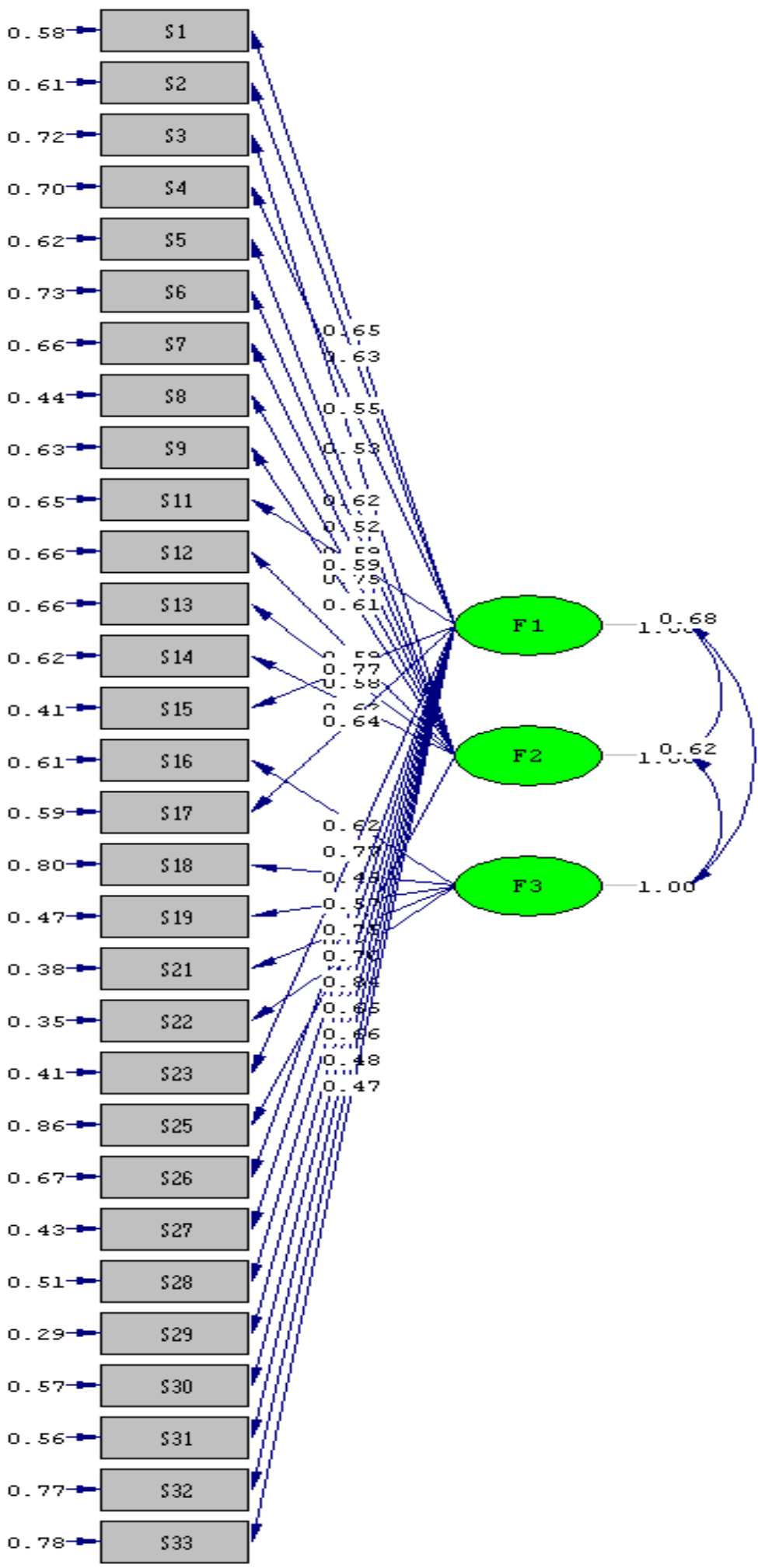

Chi-square $=1358.70 \quad \mathrm{df}=402 \quad \mathrm{p}=0.001 \quad$ RMSEA $=0.035$

Figure 3. The 3 -factor implicit structure from confirmatory factor analysis.

\section{Criterion-Related Validity}

The relationships between the total and sub-scale scores of the ABAS and the scores of other similar scales (i.e., Violence scale [VS], Behavior rating scale [BRS],
Aggression scale [AS], Youth self report [YSR/11-18]) are presented in Table 5 below.

The total score of the Aggression Scale, the physical aggression, verbal aggression, anger, hostility, and indirect aggression sub-scales of the Aggression Scale were 
significantly related to the ARNC in a positive manner, which were RC, and SJ sub-scales of ABAS and total ABAS scores. However, the RC sub-scale was not significantly related.

The Aggression Scale, total aggression score, implicit violence and explicit violence scores were significantly related to the ARNC, RC, and SJ sub-scales of the ABAS $(p<.01)$ in a positive manner. Furthermore, the Trusting sub-scale of the Aggression Scale and the total ABAS scores and ARNC, SJ sub-scales were significantly positively related $(\mathrm{p}<.05)$. There was no meaningful relationship between the RC and ARNC sub-scales.

There were positive significant relationships between the total scores of the Behavior Rating Scale and the total scores of the ABAS and between ARNC and SJ sub-scales $(p<.01)$. No significant relationship was found between total scores of the RC sub-scale and the Behavior Rating Scale.

Moreover, there was a meaningful positive relationship $(p<.01)$ between the externalizing and criminal behavior scores of the Youth Self-Report and the ARNC, RC, and SJ sub-scales. Meaningful positive relationships $(p<.05)$ were found between the Aggressive Behavior Scores and the total scores of the ABAS and the ARNC and SJ sub-scales.

All in all, t-tests were performed to determine whether the scores of the ABAS were different according to gender. The results are presented in Table 6 below.

As seen in Table 6, there were significant differences regarding gender in the three sub-scales of the ABAS and its total score. When the means were taken into consideration, this difference favored males.

To understand whether the scores of the ABAS were different based on age, Kruskal-Wallis tests were performed. To define the sources of the difference in groups found to have differences, Mann-Whitney U tests were performed. Mann Whitney U tests were preferred since the data were not normally distributed as determined with a Kolmogorov-Smirnov test. The results are presented below in Table 7.

Table 5. Correlations between ABAS Sub-scales and Other Similar Scales.

\begin{tabular}{|c|c|c|c|c|c|}
\hline \multicolumn{2}{|r|}{ Scale/Sub-Scales } & ARNC & $\mathrm{RC}$ & SJ & Total Score \\
\hline \multirow{6}{*}{$\begin{array}{l}\text { Aggression Scale } \\
\qquad(\mathrm{N}=439)\end{array}$} & Physical Aggression & $.57^{\mathrm{a}}$ & $.23^{\mathrm{a}}$ & $.23^{\mathrm{a}}$ & $.50^{\mathrm{a}}$ \\
\hline & Verbal Aggression & $.40^{\mathrm{a}}$ & $.13^{\mathrm{a}}$ & $.15^{\mathrm{a}}$ & $.34^{\mathrm{a}}$ \\
\hline & Anger & $.45^{\mathrm{a}}$ & $.14^{\mathrm{a}}$ & $.20^{\mathrm{a}}$ & $.39^{\mathrm{a}}$ \\
\hline & Hostility & $.38^{\mathrm{a}}$ & .07 & $.16^{\mathrm{a}}$ & $.31^{\mathrm{a}}$ \\
\hline & Indirect Aggression & $.47^{\mathrm{a}}$ & $.15^{\mathrm{a}}$ & $.23^{\mathrm{a}}$ & $.41^{\mathrm{a}}$ \\
\hline & Total Score of Aggression & $.55^{\mathrm{a}}$ & $.18^{\mathrm{a}}$ & $.24^{\mathrm{a}}$ & $.48^{\mathrm{a}}$ \\
\hline \multirow{4}{*}{$\begin{array}{l}\text { Violence Scale } \\
\qquad(\mathrm{N}=124)\end{array}$} & Implicit Violence & $.70^{\mathrm{a}}$ & $.47^{\mathrm{a}}$ & $.44^{\mathrm{a}}$ & $.70^{\mathrm{a}}$ \\
\hline & Explicit Violence & $.60^{\mathrm{a}}$ & $.34^{\mathrm{a}}$ & $.31^{\mathrm{a}}$ & $.56^{\mathrm{a}}$ \\
\hline & Trusting & $.23^{\mathrm{b}}$ & .06 & .15 & $.19^{\mathrm{b}}$ \\
\hline & Total Score of Violence & $.71^{\mathrm{a}}$ & $.43^{\mathrm{a}}$ & $.42^{\mathrm{a}}$ & $.68^{\mathrm{a}}$ \\
\hline \multicolumn{2}{|c|}{ Behavior Rating Scale $(\mathrm{N}=98)$} & $.57^{\mathrm{a}}$ & .10 & $.40^{\mathrm{a}}$ & $49^{\mathrm{a}}$ \\
\hline \multirow{3}{*}{$\begin{array}{l}\text { Youth Self-Report } \\
\qquad(\mathrm{N}=149)\end{array}$} & Criminal behavior & $.30^{\mathrm{a}}$ & $.28^{\mathrm{a}}$ & $.23^{\mathrm{a}}$ & $.34^{\mathrm{a}}$ \\
\hline & Aggressive Behavior & $.35^{\mathrm{a}}$ & $.19^{\mathrm{b}}$ & $.33^{\mathrm{a}}$ & $.37^{\mathrm{a}}$ \\
\hline & Total Score of Externalizing Behavior & $.36^{\mathrm{a}}$ & $.26^{\mathrm{a}}$ & $.31^{\mathrm{a}}$ & $.39^{\mathrm{a}}$ \\
\hline
\end{tabular}

Table 6. Results of t-tests of the ABAS according to Gender.

\begin{tabular}{|c|c|c|c|c|c|c|c|}
\hline Scale/Sub-Scale & Gender & $\mathrm{N}$ & $\bar{X}$ & Ss & $\mathrm{Sd}$ & $\mathrm{t}$ & $\mathrm{p}$ \\
\hline \multirow{2}{*}{ ARNC } & Girl & 1003 & 8.71 & 6.93 & \multirow{2}{*}{1936} & \multirow{2}{*}{6.03} & \multirow{2}{*}{$.000^{\mathrm{a}}$} \\
\hline & Boy & 935 & 10.62 & 6.99 & & & \\
\hline \multirow{2}{*}{$\mathrm{RC}$} & Girl & 1003 & 3.50 & 3.66 & \multirow{2}{*}{1936} & \multirow{2}{*}{5.00} & \multirow{2}{*}{$.000^{\mathrm{a}}$} \\
\hline & Boy & 935 & 4.33 & 3.66 & & & \\
\hline \multirow{2}{*}{ SJ } & Girl & 1003 & 1.05 & 1.64 & \multirow{2}{*}{1864.30} & \multirow{2}{*}{3.29} & \multirow{2}{*}{$.000^{\mathrm{a}}$} \\
\hline & Boy & 935 & 1.32 & 1.86 & & & \\
\hline \multirow{2}{*}{ Total Score } & Girl & 1003 & 13.25 & 10.25 & \multirow{2}{*}{1936} & \multirow{2}{*}{6.38} & \multirow{2}{*}{$.000^{\mathrm{a}}$} \\
\hline & Boy & 935 & 16.25 & 10.44 & & & \\
\hline
\end{tabular}


As can be seen in Table 7, age-related differences in ABAS total and sub-scale scores were tested by means of the Kruskal Wallis test. The examination of the results revealed that the ABAS total and sub-scale scores of children aged 9-11, 12-14, and 15-16 (for Total Score, ARNC, CR, and SJ, the significant differences were $\chi^{2}=438.57,18.44,88.98$ and 296.67, respectively $(p<.01)$. Mann Whitney U tests were performed to understand which groups differed. When the rank means were taken into consideration, the ARNC sub-scale scores of children aged 12-14 were significantly higher than those of children aged 9-11. Similarly, the scores of children aged $15-16$ were significantly $(p<.05)$ higher than those of children aged 9-11 and 12-14 ( $p<.05)$. Analysis of the scores of the RC sub-scale revealed no significant difference between the scores of children aged 9-11 and children aged 12-14. Additionally, the scores of children aged 15-16 were significantly $(\mathrm{p}<.05)$ higher than those of children aged 9-11 and 12-14. For the SJ sub-scale, the scores of children aged 12-14 were significantly higher than those of children aged 9-11. The scores of children aged 15-16 were also significantly $(p<.05)$ higher than those of children aged 12-14 and 9-11. For the ABAS, the scores of children aged $12-14$ were significantly $(p<.05)$ higher than those of children aged 9-11. Additionally, the scores of children aged $15-16$ were significantly $(p<.05)$ higher than those of children aged 12-14 and 9-11.

\section{Discriminant Validity of ABAS}

Mann-Whitney U tests were used to investigate whether the ABAS could discriminate the group that was involved in criminal acts from the group that was not. The results are presented in Table 8 below.

From Table 8, it can be seen that there were significant differences at the .01 level between the ABAS scores of the groups involved and not involved in crime in terms of ARNC, $\mathrm{CR}$, and total scores. In contrast, there was no significant difference between the scores of the groups involved and not involved in crime regarding SJ sub-scale ( $\mathrm{p}=.83)$.

Table 7. Results of Kruskal-Wallis and Mann-Whitney U tests on the Age Distribution of ABAS

\begin{tabular}{|c|c|c|c|c|c|}
\hline Age Range & $\mathrm{N}$ & Rank Means & $\chi^{2}$ & $\mathrm{U}$ & Relation \\
\hline \multicolumn{3}{|c|}{ ARNC } & & & \\
\hline 9-11 (1) & 647 & 628.29 & \multirow{3}{*}{$438.57^{\mathrm{a}}$} & $1-2=139206.00 *$ & $2>1$ \\
\hline $12-14(2)$ & 729 & 1020.77 & & $1-3=57666.50 *$ & $3>1$ \\
\hline $15-16(3)$ & 562 & 1295.82 & & $2-3=145600.00 *$ & $3>2$ \\
\hline \multicolumn{2}{|c|}{$\mathrm{RC}$} & & & & \\
\hline $9-11(1)$ & 647 & 913.95 & \multirow{3}{*}{$18.44^{\mathrm{a}}$} & $1-2=225309.50$ & $2=1$ \\
\hline $12-14(2)$ & 729 & 957.16 & & $1-3=156386.00^{*}$ & $3>1$ \\
\hline $15-16(3)$ & 562 & 1049.47 & & $2-3=185329.50^{*}$ & $3>2$ \\
\hline \multicolumn{3}{|c|}{ SJ } & & & \\
\hline 9-11 (1) & 647 & 828.30 & \multirow{3}{*}{$88.98^{\mathrm{a}}$} & $1-2=197115.50^{*}$ & $2>1$ \\
\hline $12-14(2)$ & 729 & 986.36 & & $1-3=129167.00^{*}$ & $3>1$ \\
\hline $15-16(3)$ & 562 & 1110.18 & & $2-3=178426.50^{*}$ & $3>2$ \\
\hline \multicolumn{6}{|c|}{ ABAS Total Score } \\
\hline 9-11(1) & 647 & 693.09 & \multirow{3}{*}{$296.67^{\mathrm{a}}$} & $1-2=160147.00^{*}$ & $2>1$ \\
\hline $12-14(2)$ & 729 & 1002.55 & & $1-3=78656.00 *$ & $3>1$ \\
\hline $15-16(3)$ & 562 & 1244.84 & & $2-3=153258.00^{*}$ & $3>2$ \\
\hline
\end{tabular}

Table 8. Results of Mann Whitney U tests of ABAS Total and Sub-Scale Scores According to Groups Involved in Criminal Acts and Groups Not Involved in Criminal Acts.

\begin{tabular}{|c|c|c|c|c|c|c|}
\hline Scale/Sub-Scale & Groups & $\mathrm{N}$ & Mean Rank & Rank Total & $\mathrm{U}$ & $P$ \\
\hline \multirow{2}{*}{ ARNC } & Groups Not Involved In Crime & 935 & 503.07 & 470375.00 & \multirow{2}{*}{32795.00} & \multirow{2}{*}{$.000^{\mathrm{a}}$} \\
\hline & Groups Involved In Crime & 85 & 592.18 & 50335.00 & & \\
\hline \multirow{2}{*}{$\mathrm{RC}$} & Groups Not Involved In Crime & 935 & 470.54 & 439957.50 & \multirow{2}{*}{2377.50} & \multirow{2}{*}{$.000^{\mathrm{a}}$} \\
\hline & Groups Involved In Crime & 85 & 950.03 & 80752.50 & & \\
\hline \multirow{2}{*}{ SJ } & Groups Not Involved In Crime & 935 & 509.94 & 476790.50 & \multirow{2}{*}{39210.50} & \multirow{2}{*}{.83} \\
\hline & Groups Involved In Crime & 85 & 516.70 & 43919.50 & & \\
\hline \multirow{2}{*}{ Total Score } & Groups Not Involved In Crime & 935 & 483.10 & 451697.00 & \multirow{2}{*}{14117.00} & \multirow{2}{*}{$.000^{\mathrm{a}}$} \\
\hline & Groups Involved In Crime & 85 & 811.92 & 69013.00 & & \\
\hline
\end{tabular}




\section{Reliability of the ABAS}

To test the resistance of sub-scale scores and total scores against time, the test-retest reliability coefficient was used. As for testing the internal consistency among scale scores, Cronbach's alpha coefficients were calculated. Results of the analysis showed that the test-retest correlations were .79 for the ARNC sub-scale, .69 for the RC sub-scale, .67 for the SJ sub-scale, and .82 for the total score. Moreover, the Cronbach's alpha internal consistency coefficients were .87 for the ARNC sub-scale, .723 for the RC sub-scale, .64 for the SJ sub-scale, and .90 for the total score.

\section{Discussion}

\section{The Construct Validity (EFA \& CFA) of the ABAS}

Testing the construct validity of the ABAS scale revealed a three-factor structure. Based on examination of the characteristics of the items loaded under the factors, the first sub-scale was named "Aggression - Rule Non-Compliance", the second sub-scale was named "Rule Compliance", and last sub-scale was named "Self-Justification".

Confirmatory factor analysis was carried out to confirm if the three-factor structure obtained revealed that the item scales were compatible with models of related structures [55, $56,57,58,59$ see Table 4]. Thus, the confirmatory factor analysis and the structured model revealed that the ABAS measures three implicit structures. Therefore, the lower dimensions can be scored independently, and the scores obtained can be used for antisocial belief and attitude levels under each dimension.

The fact that the internal consistency levels of the sub-scales were high, shows that the items were placed under the appropriate factors.

To define the relationships between the sub-scales that make up the total scale, the correlation coefficients between the sub-scales and the correlation coefficients of each scale with the total scores were calculated. The results suggest that each sub-scale of the ABAS can be used on its own as can be the total score.

\section{Criterion-Related Validity of the ABAS}

The similar and different structure validities of the scale were tested, and the findings were parallel with the literature. Kesen, Deniz, and Durmuşoğlu [60] had investigated the relationship between aggression and anger levels in teenagers and found that when anger levels in teenagers increase, aggression levels also increase. Similarly, in a study that explored the relationship between antisocial beliefs and attitudes in children who were involved in criminal acts at an early age found that antisocial beliefs are a strong risk factor for teenage crime and the anger levels and antisocial belief levels of aggressive criminals are higher than those of non-aggressive criminals [16]. Further, Loeber and Farrington [61] defined direct aggressive acts toward authority during childhood and failure to conform to rules as key behaviors predicting future involvement in crime through acts such as theft and lying.

The adapted ABAS revealed that boys had greater antisocial tendencies than girls. Studies that have examined gender differences in crime and antisocial behavior state that boys are more likely to get involved in such behaviors than girls $[14,40,46,62,63,64]$. A study that investigated gender differences, antisocial friends, and rejection of friends in the development of antisocial behavior [24] revealed that boys display higher levels of antisocial behaviors, have more antisocial friends, and are rejected more by peers compared to girls. Only a small number of girls display antisocial behavior at moderate levels and have some friends who can be considered antisocial. Moreover, a study that was concerned with gender differences in the risks of teenagers who had been exposed to domestic violence along with committing a crime found that boys and girls carry the same risks of being involved in criminal acts; however, boys appear in court more often than girls for crimes against property, murder, and violence [65]. In another study, Özbey and Alisinanoğlu [66] investigated children's behavioral problems over the age of 60-72 months and found that boys display more externalizing problems and antisocial behaviors than girls.

The reason for this gender difference could be due to the different upbringing of women and men and the social roles that are imposed on them. In our society, girls are brought up in a more repressive and conventional manner than boys. Boys, besides being physically stronger, are freer both outside and at home; thus; aggression and displays of power can be seen as more neutral for boys in the socialization process [67]. This situation can make boys more open to risks such as getting involved in gangs, having criminal peers, and getting involved in criminal acts as they are more extroverted.

Antisocial beliefs and attitudes increase with age. The majority of the relevant literature states that antisocial beliefs and attitudes start in early childhood and continue to increase until mid-adolescence (16-17 years) [14, 40, 61, 68, 69].

In adolescence, there is an increase in the importance of the environment of individuals such as close friends, and some factors, such as family relations, and thus decreasing family control on the child, the need to be a part of a group or to be accepted by others, reveal themselves. Physical strength also increases with age $[70,71,72]$. These factors may increase the tendencies of teenagers to engage in violence, criminal behaviors and/or problematic behaviors.

Many related studies state that antisocial beliefs and attitudes begin in early childhood and increase until mid-adolescence (16-17 age) [68,69]. Kaner [14] found that adolescent crime increases from the age of 15 to $17-18$. Statistics from the Ministry of Justice for accused children aged 12-15 and 16-18 reveal that crime increases with age [73]. Akduman, Akduman and Cantürk [40] carried out a 
study of adolescents aged 12-15 and found that the number of teenagers involved in criminal acts increase with age. Balat and Akman [62] carried out a study of $9^{\text {th }}, 10^{\text {th }}$, and $11^{\text {th }}$ grade students and found that problematic behaviors increase with the age of the students. From the obtained findings, it can be determined that ABAS has validity regarding gender and age for the sample in which the study was performed.

\section{Discriminant Validity of the ABAS}

The findings related to the discriminant validity of the ABAS supporting the notion that the scale can discriminate between children involved in criminal acts and those not involved with many of the dimensions of the scale and with the total scores. These findings lead us to believing that this scale can be used to identify individuals with antisocial tendencies early in life and help solve these problems just before they become chronic. The lack of a significant difference in the SJ sub-scale may be due to the similarity between the SJ or social appreciation characteristics of individuals with and without antisocial tendencies.

\section{Reliability of the ABAS}

The Cronbach's alpha internal consistency coefficients of the sub-scales of the ABAS showed that both total score and sub-scale internal consistencies were good; hence the reliability is good $[74,75]$. The Cronbach's alpha internal consistency coefficient for the SJ sub-scale was lower than the alphas for the other scales; however, it fell between acceptable intervals. This situation may be the result of the fact that the number of items on this sub-scale was low. As a whole, these findings suggest that the ABAS were internally consistent and reliable for the sample of the present study.

The test-retest reliability measurements suggest that the scale made consistent measurements, both in terms of sub-scale and total scores, and that the measurement reliability was efficient.

\section{Conclusions and Implications}

We are conscious that the study has limitations regarding some aspects such as the fact that the adapted instrument only targeted to measure the antisocial beliefs and attitudes of 9-16 year-olds, and the validity and the reliability of the study is limited with the certain sampling of the study. Additionally, in this study school-related data were not collected, making it unfeasible to look into the correlation between antisocial beliefs and attitudes with factors such as academic achievement. However, there are still some implications which can be discussed. To examine the structure validity of the ABAS, EFA and CFA were carried out. The results of CFA proved that the ABAS measures three implicit structures. In other words, the sub-scales obtained can be scored on their own. However, the ABAS was also expected to give a total antisocial attitude score. Bearing in mind, to determine whether the sub-scales of the
ABAS concentrate only on one psychological structure, a hierarchical factor analysis or a new study to develop a new scale would need to be performed. Also, the similar and different structure validity of the ABAS can be supported by qualitative and quantitative data and can be obtained from the social environment that includes the family, teacher, and peer groups. Since the scale provided information about disciplinary and behavioral problems experienced in classrooms, teachers can use the scale, and the results can be used to develop a preventive guidance program that would involve the school, the student's family, as well as the individual him/herself. Another suggestion for school context is that students at risk can be determined through the ABAS and foster them to be more involved in academic performance since studies show that low academic performance is a predictor of antisocial behavior [76, 77, 78, $79,80]$. Nevertheless, it should be kept in mind that caution ought to be taken since the development of the ABAS is still at its initial stages, and its usefulness as a clinical tool has not yet been addressed.

\section{Acknowledgements}

The study was produced by Lili Hurioğlu's (the first author) MEd thesis which supported by Çukurova University Scientific Researches Funding Unit (EF2009YL39).

\section{REFERENCES}

[1] Clark, D. B., Vanyukov, M., \& Cornelius, J. (2002). Childhood antisocial behavior and adolescent alcohol use disorders. Alcohol Research and Health, 26(2), 109-115.

[2] Lahey, B. B., Waldman, I. D., \& McBurnett, K. (1999). Annotation: The development of antisocial behavior: An integrative causal model. Journal of Child Psychology and Psychiatry, 40(5), 669-682.

[3] The Ministry of Justice, General Directorate of Judicial Records \& Statistics (2008). Çocuk mahkemeleri ve adli istatistikler, Retrieved August 01, 2010 from www.adli-sicil.gov.tr

[4] Farrington, D. P., Loeber, R., \& Van Kammen, W. B. (1990). Long-term criminal outcomes of hyperactivity-impulsivity-attention deficit and conduct problems in childhood. In L. Robins \& M. Rutter (Eds.), Straight and Devious Pathways from Childhood to Adulthood, (pp. 62-81). New York: Cambridge University Press.

[5] Loeber, R. (1990). Development and risk factors of juvenile antisocial behavior and delinquency. Clinical Psychology Review, 10(1), 1-41.

[6] Romeo, R., Knapp, M., \& Scott, S. (2006). Economic cost of severe antisocial behaviour in children-and who pays it. The British Journal of Psychiatry,188(6), 547-553.

[7] Thornberry, T. P., Lizotte, A. J., Krohn, M. D., Farnworth, M., \& Jang, S. J. (1994). Delinquent peers, beliefs, and delinquent 
behavior: a longitudinal test of interactional theory. Criminology, 32(1), 47-83.

[8] Walker, H. M., Colvin, G. \& Ramsey, E. (1995). Antisocial Behavior in School: Strategies and Best Practices. Pacific Grove, CA: Brooks/Cole.

[9] White, J. L., Moffit, T. E., Earls, F., Robins, L. \& Silva, P. A. (1990). How early can we tell?: predictors of childhood conduct disorder and adolescent delinquency. Criminology, 28(4), 507- 535.

[10] Zara G., Farrington D. P. (2009), "Childhood and Adolescent Predictors of Late Onset Criminal Careers", Journal of Youth and Adolescence, 38(3), ss. 287- 300.

[11] Hinshaw, S. P. \& Zupan, B. A. (1997). Assesment of antisocial behavior in children and adolescents. In D. Stoff, J. Breiling \& J. D. Maser (Eds.), Handbook of Antisocial Behavior, (pp. 36- 50). Canada: John Wiley and Sons Inc.

[12] Kazdin, A. E. (1987). Treatment of antisocial behavior in children: Current status and future directions. Psychological bulletin, 102(2), 187-203.

[13] Clarke, D. (2003). Prosocial and antisocial behavior. New York: Routledge.

[14] Kaner, S. (2002). Suç davranışı ölçeği geliștirme çalıșması. 1. Ulusal Çocuk ve Suç: Nedenler ve Önleme Çalışmaları Sempozyumu, Ankara, 79-90.

[15] Simourd, D. J. (1997). The Criminal Sentiments Scale-Modified and Pride in Delinquency Scale Psychometric Properties and Construct Validity of Two Measures of Criminal Attitudes. Criminal Justice and Behavior, 24(1), 52-70.

[16] Granic, I., \& Butler, S. (1998). The relation between anger and antisocial beliefs in young offenders. Personality and Individual Differences, 24(6), 759-765.

[17] Loeber, R. (1982). The stability of antisocial and delinquent child behavior: A review. Child Development, 53, 1431-1446.

[18] Shamsie, J., Sykes, C., \& Hamilton, H. (1994). Continuity of care for conduct disordered youth. The Canadian Journal of Psychiatry/La Revue Canadienne de Psychiatrie, 39(7), 415-420.

[19] Dishion, T. J., French D. \& Patterson, G. (1995). The development and ecology of antisocial behavior. In D. Cicchetti \& D. J. Cohen (Eds.), Developmental Psychopathology, (pp. 421-471). UK: Wiley.

[20] Loeber, R., \& Hay, D. (1997). Key issues in the development of aggression and violence from childhood to early adulthood. Annual Review of Psychology, 48(1), 371-410.

[21] Mitchell, S., \& Rosa, P. (1981). Boyhood behaviour problems as precursors of criminalty: A fifteen - year follow - up study. Journal of Child Psychology and Psychiatry, 22(1), 19-33.

[22] Moffit, T. E., Caspi, A., Rutter, M. \& Silva, P.A. (2001). Sex Differences in Antisocial Behaviour: Conduct Disorder, Delinquency, and Violence in the Dunedin Longitudinal Study. Edinburg: Cambridge University Press.

[23] Eme, R. F., \& Kavanaugh, L. (1995). Sex differences in conduct disorder. Journal of Clinical Child Psychology, 24(4), 406-426.
[24] Fagan, J. (1990). The interaction between child sex and temperament in predicting behavior problems of preschool age children in day care. Early Child Development and Care, 59(1), 1-9.

[25] Van Lier, P. A., Vuijk, P., \& Crijnen, A. A. (2005). Understanding mechanisms of change in the development of antisocial behavior: The impact of a universal intervention. Journal of Abnormal Child Psychology, 33(5), 521-535.

[26] Tuvblad, C., Eley, T. C., \& Lichtenstein, P. (2005). The development of antisocial behaviour from childhood to adolescence. European Child \& Adolescent Psychiatry, 14(4), 216-225.

[27] Nagin, D. S., Farrington, D. P., \& Moffitt, T. E. (1995). Life - course trajectories of different types of offenders. Criminology, 33(1), 111-139.

[28] Farrington, D. P. \& West, D. J. (1981). The Cambridge Study in Delinquent Development. In S. A. Mednick \& A. E. Baert (Eds.), Prospective Longitudinal Research: An Empirical Basis for the Primary Prevention of Psychosocial Disorders, (pp. 137-145). Oxford: Oxford University Press.

[29] Mak, A. S. (1990). Testing a psychosocial control theory of delinquency. Criminal Justice and Behavior, 17(2), 215-230.

[30] Elliot, D. S. (1994). Serious violent offenders: Onset, developmental course, and termination. Criminology, 32(1), 1- 21 .

[31] Farrington, D. P. (1989), "Early Predictors of Adolescent Aggression and Adult Violence", Violence and Victims, 4 (2), ss. $79-100$.

[32] Maguin, E., Hawkins, J. D., Catalano, R. F., Hill, K., Abbott, R., \& Herrenkohl, T. (1995). Risk factors measured at three ages for violence at age 17-18. American Society of Criminology, Boston.

[33] Williams, J. H. (1994). Understanding substance use, delinquency involvement, and juvenile justice involvement among African- American and European American adolescents. Unpublished doctoral dissertation, University of Washington, Seattle, WA.

[34] Zhang, Q., Loeber, R., \& Stouthamer-Loeber, M. (1997). Developmental trends of delinquent attitudes and behaviors: Replications and synthesis across domains, time, and samples. Journal of Quantitative Criminology, 13(2), 181-215.

[35] Evans, S. E., Davies, C., \& DiLillo, D. (2008). Exposure to domestic violence: A meta-analysis of child and adolescent outcomes. Aggression and Violent Behavior, 13(2), 131-140. doi: DOI 10.1016/j.avb.2008.02.005

[36] Ibabe, I., Arnoso, A., \& Elgorriaga, E. (2014). Behavioral problems and depressive symptomatology as predictors of child-to-parent violence. European Journal of

[37] The Turkey Statistical Institute [TSI] (2009). The Number of Children Who Ended Up in Security Departments in 27 Cities in Relation to Year and Gender. Statistical Tables, Retrieved July 30, 2009 from http://www.tuik.gov.tr

[38] Köknel, Ö. (2001). Kimliğini arayan gençliğimiz (1. Bask1). İstanbul: Altın Kitaplar Yayınevi.

[39] Avcı, M. (2008). Tutuklu çocuklar üzerine bir araştırma: çocukların suça yönelmesinde etkili olan toplumsal nedenler ve çözüm önerileri. Journal of Graduate School of Social 
Sciences, 11(1), 49-73.

[40] Kocadaş, B. (2007). The relationship of lower social-economic structure child crime in Malatya. Sosyoloji Araştırmaları Dergisi, 10(1), 157-186.

[41] Akduman, G. G., Akduman, B.\& Cantürk, G. (2007). Investigation of the some personal and familial characteristics of juvenile delinquency. Turkish Archives of Pediatrics, 42, 156-161.

[42] Hambleton, R. K., \& Kanjee, A. (1995). Increasing the validity of cross-cultural assessments: Use of improved methods for test adaptations. European Journal of Psychological Assessment, 11(3), 147-157.

[43] Hambleton, R. K., \& Patsula, L. (1998). Adapting tests for use in multiple languages and cultures. Social Indicators Research, 45(1-3), 153-171.

[44] Savaşır, I. (1994). Ölçek uyarlamasındaki sorunlar ve bazı çözüm yolları. Türk Psikoloji Dergisi, 9(33), 27- 32.

[45] Şahin, N. (1994). Psikoloji araştırmalarında ölçek kullanımı. Türk Psikoloji Dergisi, 9(33), 19-26.

[46] Deniz, K. Z. (2007). The adaptation of psychological scales. Ankara University, Journal of Faculty of Educational Sciences, 40(1), 1-16.

[47] Butler, S. M., Leschied, A. W., \& Fearon, P. (2007). Antisocial beliefs and attitudes in pre-adolescent and adolescent youth: the development of the antisocial beliefs and attitudes scales (ABAS). Journal of Youth and Adolescence, 36(8), 1058-1071.

[48] Andrews, D. A. \& Bonta, (1998). The psychology of criminal conduct. (2nd ed.). Cincinnati, OH: Andersen Publ.

[49] Yavuz, N. (2009). To be analyzed the violence inclinations of the 7 and 8 graders students of primary school in terms of will-rounded variables, the sample of Kocaeli province and district of Gebze, Unpublished master's thesis. Yeditepe University, İstanbul.

[50] Karakaya, E. (2008). Multi directional evaluation and investigation of students educated in vocational high schools concerning with inclination of violence attack and harmful behavior. Unpublished master's thesis, Yeditepe University, İstanbul.

[51] Şahin, H. (2004). Saldırganlık Ölçeği Geçerlik Güvenirlik Çalışması. Burdur Eğitim Fakültesi Dergisi, 5(7), 180-190.

[52] Buss AH, Warren WL. (2000). Aggression questionnaire-manual. Los Angeles, CA: Western Psychological Services.

[53] [52] Can, S. (2002). Validity and reliability of a scale called "Aggression Questionnare" in Turkish Population. Unpublished doctoral dissertation. Turkish General Staff, Gülhane Military Medical Academy, Haydarpaşa Teaching Hospital, Mental Health and Disease Chieftaincy, İstanbul.

[54] Achenbach, T. M., \& Edelbrock C. (1987). Manual for the Youth-Self Report and Profile. Burlington: University of Vermont, Department of Psychiatry.

[55] Erol, N. \& Şimsek, Z. (1998). Türkiye ruh sağlı̆̆1 profili: Çocuk ve gençlerde ruh sağlığı, yeterlik alanları, davranış ve duygusal sorunların dağılımı. N. Erol, C. Kılıc, , M. Ulusoy, M. Kececi \& Z. Simsek (Eds.), Türkiye Ruh Sağlığı Profili
Raporu, (pp. 25-75). Ankara: T.C. Sağlık Bakanlığ 1 Temel Sağlık Hizmetleri Genel Müdürlüğü, Eksen Tanıtım Ltd. Şti.

[56] Kline, R. B. (2005). Principles and practice of structural equation modeling, (2nd ed.), New York, London: The Guilford Press

[57] Joreskog, K. G., \& Sorbom, D. (1993). LISREL8: Structural equation modeling with the SIMPLIS command language. Hillsdale, NJ: Erlbaum.

[58] Hu, L. T. \& Bentler, P. M. (1999). Cutoff criteria for fit indexes in covariance structure analysis: Conventional criteria versus new alternatives. Structural Equation Modeling: a Multidisciplinary Journal, 6(1), 1-55.

[59] Tabachnick, B. C., Fidell, L. S. (2001). Using multivariate statistics (4th ed.), Needham Heights, MA: Allyn and Bacon.

[60] Yılmaz, V. Çelik, E. (2009). Lisrel ile yapısal eşitlik modellemesi-I. (I. Bask1), Ankara: Pegem Akademi Yayıncilık.

[61] Kesen, N., Deniz, M., \& Durmuşoğlu, N. (2007). Ergenlerde saldırganlık ve öfke düzeyleri arasındaki ilişki: Yetiștirme yurtları üzerinde bir araştırma. Selçuk Üniversitesi Sosyal Bilimler Enstitüsü Dergisi, 17, 353-364.

[62] Loeber, R., \& Farrington, D. P. (1998). Serious and violent juvenile offenders: Risk factors and successful interventions. Thousand Oaks, CA: Sage Publications.

[63] Balat, G. U., \& Akman, B. (2006). Lise öğrencilerinin psikolojik durumlarinin sosyodemografik özelliklerine göre incelenmesi. Çocuk ve Gençlik Ruh Sağliği Dergisi, 13(1), $3-12$.

[64] Del Valle, N. Q., Velázquez, J. A. V., García, F. J., López, M. d. L. G., Buenabad, N. G. A., \& Icaza, M. E. M.-M. (2007). La familia y el maltrato como factores de riesgo de conducta antisocial. Salud Mental, 30(4), 47-54.

[65] Sullivan, C. J. (2006). Early Adolescent Delinquency Assessing the Role of Childhood Problems, Family Environment, and Peer Pressure. Youth Violence and Juvenile Justice, 4(4), 291-313.

[66] Herrera, V. M., \& McCloskey, L. A. (2001). Gender differences in the risk for delinquency among youth exposed to family violence. Child Abuse \& Neglect, 25(8), 1037-1051.

[67] Özbey, S., \& Alisinanoğlu, F. (2009). A study on problem behavior of 60-72 months children who attending public early childhood education institution. The Journal of International Social Research, 2(6), 493-517.

[68] Celik, Ö. (2008). The internalization of social sex and sex roles in terms of Patriarchal System. Unpublished master's thesis, Gazi University, Social Sciences Institute, Ankara.

[69] Patterson, G. R. Debaryshe, B. and Ramsey, E. (1990), “A Developmental Perspective on Antisocial Behavior", American Psychologist, 44, ss. 329-335.

[70] Thornberry, T. P. (2006). Developmental Theories of Crime and Delinquency (3th ed.). United States of America: Transaction Publishers.

[71] Malrieu, P. (1987). Ergenlikte Toplumsallaşma. In B. Onur (Ed.), Ergenlik Psikolojisi, (pp. 231-246). Ankara: Hacettepe-Taş Kitapçılık Ltd. Şti. 
[72] Siyez, D. (2009). Ergenlerde problem davranışlar. Ankara: Pegem Akademi Yayıncılık.

[73] Yavuzer, H. (1992). Anne-Baba ve Çocuk (5. Bask1), İstanbul: Remzi Kitabevi.

[74] Republic of Turkey, Ministry of Justice (2015). Mahkum Karar Nitelikleri, Retrieved March 23, 2015 from www.adlisicil.adalet.gov.tr/istatistik 2013/87.pdf

[75] George, D. \& Mallery, P. (2003). SPSS for windows step by step: A simple guide and reference. 11.0 update (4th ed.), Boston: Allyn and Bacon.

[76] Kalaycı, Ş. (2008). SPSS uygulamalı çok değişkenli istatistik teknikleri (3. Baskı). Ankara: Asil Yayın Dağıtım Ltd. Şti.

[77] Hawkins, J. D., Farrington, D. P., \& Catalano, R. F. (1998). Reducing violence through the schools. In D. S. Eliot, B. A. Hamburg, \& K. R. Williams (Eds.), Violence in American schools: A new perspective, (pp. 188-216). Cambridge, UK: Cambridge University Press.
[78] Herrenkohl, T., Maguin, E., Hill, K., Hawkins, J., Abbott, R., \& Catalano, R (1998). Childhood and adolescent predictors of youth violence. Seattle: University of Washington, Seattle Social Development Project.

[79] Huizinga, D., \& Jakob-Chien, C. (1998). The contemporaneous co-occurrence of serious and violent juvenile offenders and other problem behaviors. In R. Loeber \& D. Farrington (Eds.), Serious \& violent juvenile offenders: Risk factors and successful interventions (pp. 47-67). Thousand Oaks, CA: Sage.

[80] Lipsey, M. W., \& Derzon, J. (1998). Predictors of violent or serious delinquency in adolescence and early adulthood: A synthesis of longitudinal research. In R. Loeber \& D. P. Farrington (Eds.), Serious and violent juvenile offenders: Risk factors and successful interventions (pp. 86-105). Thousand Oaks, CA: Sage.

[81] Maguin, E., \& Loeber, R. (1996). Academic performance and delinquency. Crime and Justice, 20, 145-264. 